\title{
Effect of inclusion of different levels of Leucaena silage on rumen microbial population and microbial protein synthesis in dairy steers fed on rice straw
}

\author{
Thien Truong Giang Nguyen ${ }^{1}$, Metha Wanapat ${ }^{1, *}$, Kampanat Phesatcha ${ }^{1}$, and Sungchhang Kang ${ }^{2}$
}

\section{* Corresponding Author: Metha Wanapat Tel: +66-4320-2368, Fax: +66-4320-2368, E-mail: metha@kku.ac.th}

'Tropical Feed Resources Research and Development Center (TROFREC), Department of Animal Science, Faculty of Agriculture, Khon Kaen University, Khon Kaen 40002, Thailand

${ }^{2}$ Agricultural Unit, Department of Education, National Institute of Education, Phnom Penh 12410, Cambodia

Submitted Nov 20, 2015; Revised Mar 18, 2016; Accepted Apr 10, 2016
Objective: Leucaena leucocephala (Leucaena) is a perennial tropical legume that can be directly grazed or harvested and offered to ruminants as hay, silage, or fresh. However, Leucaena contain phenolic compounds, which are considered anti-nutritional factors as these may reduce intake, digestibility and thus animal performance. Therefore, the objective of this experiment was to determine effects of Leucaena silage (LS) feeding levels on rumen microbial populations, $\mathrm{N}$-balance and microbial protein synthesis in dairy steers.

Methods: Four, rumen fistulated dairy steers with initial weight of $167 \pm 12 \mathrm{~kg}$ were randomly assigned to receive dietary treatments according to a $4 \times 4$ Latin square design. Treatments were as followings: $\mathrm{T} 1=$ untreated rice straw (RS; Control), $\mathrm{T} 2=70 \% \mathrm{RS}+30 \% \mathrm{LS}, \mathrm{T} 3=40 \%$ RS $+60 \%$ LS, and T4 $=100 \%$ LS. Dairy steers were fed rice straw and LS ad libitum and supplemented with concentrate at $0.2 \%$ of body weight/d.

Results: Results revealed that the rumen microbial population, especially cellulolytic, proteolytic bacteria and fungal zoospores were enhanced in steers that received $60 \%$ of LS $(p<0.05)$, whereas the amylolytic bacteria population was not affected by treatments $(\mathrm{p}>0.05)$. Protozoal population was linearly decreased with increasing level of LS $(p<0.05)$. Moreover, N-balance and microbial protein synthesis were enhanced by LS feeding $(\mathrm{p}<0.05)$ and were the highest in $60 \%$ LS group.

Conclusion: Based on this study, it could be concluded that replacement of RS with 60\% LS significantly improved microbial population and microbial protein synthesis in diary steers.

Keywords: Dairy Steers, Leucaena Silage, Microbial Population, Microbial Protein Synthesis, Rice Straw

\section{INTRODUCTION}

Feed resources for ruminants are mainly agricultural by-products, especially in the tropical countries where the roughage resources are in shortage during the dry season. These resources have low nutritive values with low crude protein $(\mathrm{CP})$ but with high levels of ligno-cellulosic, hence can reduce on animal production [1]. Protein is the most important factor in maintaining the rumen ecosystem, stimulating dry matter intake as well as digestibility, and leading to high animal performance. Therefore, supplementation of the diet with protein concentrate will enhance rumen bacterial population, improving intake and digestibility. However, the price of concentrate is relatively high and not always available. To solve this problem, finding locally available protein supplemental resources especially fodder trees and shrub legumes such as Leucaena leucocephala (Leucaena) or Flemingia macrophylla have been recommended [2].

Leucaena, a local available tree legume, was used for ruminants due to its good characteristics such as high protein, palatability, vitamin, and mineral especially sulfur content, which pos- 
itively effects microbial populations [3]. In addition, Leucaena has high digestibility of protein and dry mater (DM) at 60 to $70 \%$ [4]. Moreover, Leucaena has been reported to contain plant secondary compounds such as condensed tannin (CT), which could be beneficial in reducing protozoal populations leading to a reduced emission of ruminal methane. However, there is still limited data on the use of Leucaena silage (LS) as high quality roughage for ruminants and its effect on rumen ecology and performances. Therefore, the objective of this study was to investigate the effect of replacing rice straw (RS) with LS levels on microbial populations and microbial protein synthesis in dairy steers.

\section{MATERIALS AND METHODS}

Animals, diets and experimental design

Preparation of LS was as follows: Leucaena was harvested and chopped into 2 to $3 \mathrm{~cm}$ lengths, then ensiled with urea and molasses at $1.0 \%$ and $2.0 \% \mathrm{DM}$, respectively, packed in plastic boxes and pressed well to remove air. The duration of ensilage time was at least two weeks before offering to experimental dairy steers.

Four, rumen fistulated dairy steers with initial weight of $167 \pm$ $12 \mathrm{~kg}$ were randomly assigned to receive four diets according to a $4 \times 4$ Latin square design. All animals were kept in individual pens; water and mineral block were provided at all times. Animals were supplemented with concentrate at $0.2 \%$ of body weight/d. The treatments were as follows: $\mathrm{T} 1=$ untreated RS (Control), $\mathrm{T} 2=70 \% \mathrm{RS}+30 \% \mathrm{LS}, \mathrm{T} 3=40 \% \mathrm{RS}+60 \% \mathrm{LS}$, and $\mathrm{T} 4=100 \%$ LS. Animals were fed twice per day in the morning (07:00) and afternoon (16:00). The experiment was carried out for four periods. Each period lasted for 21 days; during the first 14 days feed intake was measured, while the last 7 days dairy steers were moved to the metabolism crates for total collection of feces and urine. Feed ingredients and composition of concentrate, RS and LS are presented in Table 1.

\section{Data collection and sampling procedures}

Feed sampling procedures: Feed offered and refusals were recorded daily throughout the experimental period. Feed samples were randomly collected twice a week for DM analysis using hot air oven at $100^{\circ} \mathrm{C}$ for 24 hours [5]. Samples of feed and feces were collected daily during the last 7 days of each period by total collection method. The feces were sampled about $50 \mathrm{~g} / \mathrm{kg}$ of total fresh weight and divided into two parts; the first part was for analysis of DM [5] daily during the collection days and the second part was kept in refrigerator and pooled by each steer at the end of each period. Samples of dietary feed were composited by period. All samples were stored in the freezer at $-20^{\circ} \mathrm{C}$ for chemical analysis in the laboratory. Feeds, feed refusals and fecal samples were dried at $60^{\circ} \mathrm{C}$ for 48 hours and ground (1 mm screen using the Cyclotech Mill, Tecator, Höganäs,
Table 1. Feed ingredients and estimated chemical compositions of dietary treatments used in the experiment

\begin{tabular}{|c|c|c|c|}
\hline Items & Concentrate & Rice straw & $\begin{array}{c}\text { Leucaena } \\
\text { silage }\end{array}$ \\
\hline \multicolumn{4}{|l|}{ Ingredients (\%) } \\
\hline Rice bran & 13.7 & & \\
\hline Coconut meal & 10.0 & & \\
\hline Palm kernel meal & 9.0 & & \\
\hline Cassava chip & 69.0 & & \\
\hline Urea & 2.5 & & \\
\hline Molasses & 3.0 & & \\
\hline Salt & 1.0 & & \\
\hline Sulfur & 0.5 & & \\
\hline Premix & 1.0 & & \\
\hline \multicolumn{4}{|l|}{ Chemical composition (\%) } \\
\hline Dry matter & 89.5 & 89.7 & 30.3 \\
\hline Organic matter & 93.6 & 88.6 & 90.9 \\
\hline Crude protein & 13.9 & 2.4 & 25.1 \\
\hline Neural detergent fiber & 19.3 & 78.9 & 36.2 \\
\hline Acid detergent fiber & 9.5 & 62.5 & 21.4 \\
\hline Condensed tannins & - & - & 2.8 \\
\hline
\end{tabular}

Sweden) for chemical analysis using standard methods of AOAC [5] for DM, ash, and CP. Acid detergent fiber was determined according to an AOAC method [5] and was expressed by inclusive of residual ash. Neutral detergent fiber was estimated according to Goering and Van Soest [6] with addition of a-amylase without sodium sulphite and the result was expressed with residual ash. Sample LS was analyzed for CT using the VanillinHCL method $[7,8]$.

Urine sampling procedures: Total urine was collected on the same days as feces by using plastic container fixed with sulfuric acid $(10 \%)$ to protect nitrogen $(\mathrm{N})$ loss. The urinary samples were collected about $100 \mathrm{~mL} / \mathrm{L}$ of the total volume urine, kept in refrigerator, and then pooled at the end of each period for total $\mathrm{N}$ analysis according to [5] for determining $\mathrm{N}$ utilization. The allantoin in the urine was determined by High Pressure Liquid Chromatography according to Chen et al [9] (HPLC, Instrument by controller water model 1525; water model 2707 auto sampler; water model 2489 UV detector and BREEZE software, Water Corp., Milford, Massachusetts, USA; A 3.9 $\mathrm{mm} \times 300 \mathrm{~mm}$ stainless-steel column, packed with ReproGel $\mathrm{H}$ and a pre-column, packed with the same material were used). The mobile phase consisted of $10 \mathrm{mM} \mathrm{H}_{2} \mathrm{PO}_{4}(\mathrm{pH} 2.5)$ and the flow rate was $0.8 \mathrm{~mL} / \mathrm{min}$. The UV detector (at $210 \mathrm{~nm}$ ) was used for quantification. The UV-Visible spectra were recorded at the peak maxima and were corrected for the solvent background. The results were determined, using the standard volatile acids (Merck, India) as control. The amount of microbial purines derivative $(\mathrm{PD})$ absorption $(\mathrm{X} \mathrm{mmol} / \mathrm{d}$ ) corresponding to the $\mathrm{PD}$ excretion ( $\mathrm{Y} \mathrm{mmol} / \mathrm{d}$ ) was calculated basing on the relationship derived by Chen and Gomes [10]: $\mathrm{Y}=0.85 \mathrm{X}+\left(0.385 \mathrm{~W}^{0.75}\right)$. The supply of microbial $\mathrm{N}(\mathrm{MN})$ was estimated by urinary ex- 
cretion of PD according to Chen and Gomes [10]: $\mathrm{MN}$ (g/d) $=70 \mathrm{X} /(0.116 \times 0.83 \times 1,000)=0.727 \mathrm{X}$; where $\mathrm{X}$ is $\mathrm{PD}$ absorption in $\mathrm{mmol} / \mathrm{d}$, digestibility of microbial purine is 0.83 , the $\mathrm{N}$ content of purines is $70 \mathrm{mg} \mathrm{N} / \mathrm{mmol}$, and the ratio of purine- $\mathrm{N}$ : total $\mathrm{N}$ in mixed rumen microbes is 11.6:100. The efficiency of microbial $\mathrm{N}$ synthesis (EMNS) to denote the MN supplied to the animal per unit of digestible organic matter apparently fermented in the rumen (DOMR) was calculated using the following formula: EMNS $=\mathrm{MN}(\mathrm{g} / \mathrm{d}) / \mathrm{DOMR}$ (assuming that rumen digestion was $650 \mathrm{~g} / \mathrm{kg}$ organic matter $(\mathrm{OM})$ of digestion in total tract, $\mathrm{DOMR}=\mathrm{DOMI} \times 0.65 ; \mathrm{DOMI}=$ digestible organic matter intake).

Rumen fluid procedures: Rumen fluid samples were collected at $0,2,4,6 \mathrm{~h}$ post-feeding. Approximately $200 \mathrm{~mL}$ of rumen fluid was taken from the middle part of the rumen each time at the end of each period. Rumen fluid samples were filtered through four layers of cheesecloth. The samples were divided into two portions. The first portion of $1 \mathrm{~mL}$ rumen fluid was collected and kept in a plastic bottle to which $9 \mathrm{~mL}$ of $10 \mathrm{~mL} / \mathrm{L}$ formalin solution ( $1: 9 \mathrm{v} / \mathrm{v}$, rumen fluid: $10 \mathrm{~mL} / \mathrm{L}$ formalin) was added and stored at $4^{\circ} \mathrm{C}$ for determining bacteria, protozoal and fungi population by using total direction counts according to Galyean [11] by haemacytometer (Boeco, Hamburg, Germany). The second portion was quantified ruminal microorganism (cellulolytic, proteolytic, amylolytic, and total viable count bacteria) using the viable count of bacteria, based on the use of a roll-tube technique [12].

\section{Statistical analysis}

All data obtained from the experiment were subjected to analysis of variance for a $4 \times 4$ Latin square design using the general linear models (GLM) procedures of the Statistical Analysis System Institute [13]. Data were analyzed using the model $Y_{\mathrm{ijk}}=\mu+\mathrm{M}_{\mathrm{i}}+$ $\mathrm{A}_{\mathrm{j}}+\mathrm{P}_{\mathrm{k}}+\varepsilon_{\mathrm{ijk}}$ where $\mathrm{Y}_{\mathrm{ijk}}$ is the observation from animal j; receiving diet $i$, in period $k$; $\mu$, the overall mean; $M_{i}$, effect of treatment ( $i=1$ to 4$) ; A_{j}$, the effect of animal $(j=1$ to 4$) ; P_{k}$, the effect of period ( $\mathrm{k}=1$ to 4$)$; and $\varepsilon_{\mathrm{ijk}}$, the residual effect. Treatment means were compared by Duncan's new multiple range test (DMRT) [14]. Differences among means with $\mathrm{p}<0.05$ were accepted as statistically significant differences.

\section{RESULTS}

Effect of diet on bacteria, protozoa and anaerobic fungi The effects of LS replacement with RS on ruminal microorganisms using direct count method are presented in Table 2. The mean values of microbial count, protozoal and fungal zoospores were remarkably different among treatments $(\mathrm{p}<0.05)$. The bacterial and zoospores population were highest in RS replacement with $60 \%$ LS and followed by $30 \%$ LS and 100\% LS, and RS diets with results ranging from $3.6 \times 10^{10}$ to $5.9 \times 10^{10}$ and $2.2 \times 10^{4}$ to $3.4 \times 10^{4}$ cells $/ \mathrm{mL}$, respectively. Whereas, mean values of protozoa
Table 2. Effect of Leucaena silage feeding levels on total direct count of bacteria, protozoa and anaerobic fungi in dairy steers

\begin{tabular}{lcccccc}
\hline $\begin{array}{c}\text { Direct count } \\
\text { (cells/mL) }\end{array}$ & RST & RLS30 & RLS60 & LS & SEM & $\begin{array}{c}\text { Significant } \\
\text { level }\end{array}$ \\
\hline $\begin{array}{l}\text { Bacteria }\left(\times 10^{10}\right) \\
\quad \text { h post feeding }\end{array}$ & $2.2^{\mathrm{a}}$ & $3.1^{\mathrm{b}}$ & $4.2^{\mathrm{c}}$ & $2.8^{\mathrm{b}}$ & 0.56 & $*$ \\
4 & $4.9^{\mathrm{a}}$ & $6.2^{\mathrm{b}}$ & $7.5^{\mathrm{c}}$ & $5.5^{\mathrm{d}}$ & 0.52 & $*$ \\
$\quad$ Mean & $3.6^{\mathrm{a}}$ & $4.7^{\mathrm{b}}$ & $5.9^{\mathrm{c}}$ & $4.2^{\mathrm{d}}$ & 0.48 & $*$ \\
Protozoa $\left(\times 10^{5}\right)$ & & & & & & \\
$\quad$ h h post feeding & $6.1^{\mathrm{a}}$ & $5.4^{\mathrm{b}}$ & $4.4^{\mathrm{c}}$ & $3.7^{\mathrm{d}}$ & 0.44 & $*$ \\
4 & $8.2^{\mathrm{a}}$ & $6.2^{\mathrm{b}}$ & $5.3^{\mathrm{c}}$ & $4.3^{\mathrm{d}}$ & 0.59 & $*$ \\
$\quad$ Mean & $7.2^{\mathrm{a}}$ & $5.8^{\mathrm{b}}$ & $4.9^{\mathrm{c}}$ & $4.0^{\mathrm{d}}$ & 0.46 & $*$ \\
Fungal zoospore $\left(\times 10^{4}\right)$ & & & & & & \\
0 h post feeding & $1.1^{\mathrm{a}}$ & $2.2^{\mathrm{b}}$ & $2.3^{\mathrm{b}}$ & $1.5^{\mathrm{c}}$ & 0.29 & $*$ \\
4 & $3.3^{\mathrm{a}}$ & $4.0^{\mathrm{b}}$ & $4.4^{\mathrm{c}}$ & $3.7^{\mathrm{d}}$ & 0.31 & $*$ \\
Mean & $2.2^{\mathrm{a}}$ & $3.2^{\mathrm{b}}$ & $3.4^{\mathrm{c}}$ & $2.7^{\mathrm{d}}$ & 0.26 & $*$ \\
\hline
\end{tabular}

Condensed tannins intake in each treatments was $0.0,28.6,62.2$, and $92.4 \mathrm{~g} /$ head/d for RST, RLS30, RLS60, and LS, respectively: RST, rice straw; RLS30, 70\% rice straw $+30 \%$ Leucaena silage; RLS60, 40\% rice straw+60\% Leucaena silage; LS, 100\% Leucaena silage; SEM, standard error of the means.

a,b,c,d Means in the same row with different superscript differ $\left({ }^{*} p<0.05\right)$.

were decreased together with increased replacement level of RS with LS and the values were $4 \times 10^{5}$ to $7.2 \times 10^{5}$ cells $/ \mathrm{mL}$.

Effect of diet on amylolytic bacteria, proteolytic bacteria and cellulolytic bacteria

Table 3 shows the effects of LS feeding level affected on viable bacterial population by using roll-tube in dairy steers. Mean values of amylolytic population remained unchanged among treatments, while cellulolytic bacterial and proteolytic bacterial populations were significantly increased $(\mathrm{p}<0.05)$ with an increasing level of LS. The number of cellulolytic and proteolytic bacteria were the highest in 60\% LS feeding and the values were

Table 3. Effects of Leucaena silage feeding levels on viable bacteria by using rolltube technique in dairy steers

\begin{tabular}{lcccccc}
\hline $\begin{array}{l}\text { Viable bacteria } \\
\text { (cfu/mL) }\end{array}$ & RST & RLS30 & RLS60 & LS & SEM & $\begin{array}{c}\text { Significant } \\
\text { level }\end{array}$ \\
\hline $\begin{array}{l}\text { Amylolytic }\left(\times 10^{7}\right) \\
\quad \text { h post feeding }\end{array}$ & 1.1 & 1.2 & 1.4 & 1.0 & 0.48 & ns \\
4 & 2.0 & 2.2 & 2.3 & 1.8 & 0.61 & ns \\
$\quad$ Mean & 1.6 & 1.7 & 1.9 & 1.4 & 0.50 & ns \\
Proteolytic $\left(\times 10^{7}\right)$ & & & & & & \\
$\quad$ h post feeding & $1.8^{\mathrm{a}}$ & $2.4^{\mathrm{b}}$ & $2.5^{\mathrm{b}}$ & $2.1^{\mathrm{c}}$ & 0.40 & $*$ \\
4 & $3.3^{\mathrm{a}}$ & $4.8^{\mathrm{b}}$ & $5.4^{\mathrm{c}}$ & $3.8^{\mathrm{d}}$ & 0.35 & $*$ \\
$\quad$ Mean & $2.6^{\mathrm{a}}$ & $3.7^{\mathrm{b}}$ & $4.0^{\mathrm{c}}$ & $3.0^{\mathrm{d}}$ & 0.32 & $*$ \\
Cellulolytic $\left(\times 10^{8}\right)$ & & & & & & \\
O h post feeding & $3.0^{\mathrm{a}}$ & $5.2^{\mathrm{b}}$ & $5.3^{\mathrm{b}}$ & $3.6^{\mathrm{c}}$ & 0.44 & $*$ \\
4 & $4.4^{\mathrm{a}}$ & $7.0^{\mathrm{b}}$ & $7.5^{\mathrm{c}}$ & $4.7^{\mathrm{d}}$ & 0.36 & $*$ \\
Mean & $3.6^{\mathrm{a}}$ & $6.2^{\mathrm{b}}$ & $6.4^{\mathrm{c}}$ & $4.2^{\mathrm{d}}$ & 0.35 & $*$ \\
\hline
\end{tabular}

Condensed tannins intake in each treatments was $0.0,28.6,62.2$, and $92.4 \mathrm{~g} / \mathrm{head} / \mathrm{d}$ for RST, RLS30, RLS60, and LS, respectively: RST, rice straw; RLS30, 70\% rice straw $+30 \%$ Leucaena silage; RLS60, 40\% rice straw+60\% Leucaena silage; LS, 100\% Leucaena silage; ns, non-significantly different; SEM, standard error of the means.

a,b,c,d Means in the same row with different superscript differ $\left({ }^{*} p<0.05\right)$. 
at $6.4 \times 10^{8}$ and $4.0 \times 10^{7}$ cells $/ \mathrm{mL}$, respectively.

Effect of diet nitrogen balance and efficiency of microbial protein synthesis

The effects of LS feeding levels on $\mathrm{N}$ balance and microbial protein synthesis in dairy steers are presented in Table $4 . \mathrm{N}$ balance in terms of $\mathrm{N}$ intake, $\mathrm{N}$ fecal excretion and $\mathrm{N}$ urinary excretion were linearly increased with increasing levels of LS in the diets $(\mathrm{p}<0.01)$ and the values ranged from 17.8 to $125.8 \mathrm{~g} / \mathrm{d}, 8.5$ to $50.9 \mathrm{~g} / \mathrm{d}$ and 4.6 to $30 \mathrm{~g} / \mathrm{d}$, respectively. $\mathrm{N}$ absorption was significantly different among treatments $(\mathrm{p}<0.05)$ and the highest was in $60 \%$ LS and $100 \%$ LS. Present findings also revealed that $\mathrm{N}$ retention was the highest in $60 \% \mathrm{LS}(45 \mathrm{~g} / \mathrm{d})$. On the other hand, allantoin excretion and absorption were markedly affected $(\mathrm{p}<0.05)$ among diets and were the highest in dairy steers receiving $60 \%$ LS ration ( 44.0 to 84.8 and 30.2 to $77.2 \mathrm{mmol} / \mathrm{d}$, respectively). The $\mathrm{MN}$ supply significantly differed among diets and was highest in 60\% LS (56.1 g/d). Efficiency of MN synthesis was the highest in the steer that consumed 60\% LS and followed by $30 \% \mathrm{LS}, 100 \% \mathrm{LS}$, and $0 \% \mathrm{LS}$, respectively.

\section{DISCUSSION}

Effect of diet on bacteria, protozoa and anaerobic fungi The protozoal population decreased with increasing LS feeding levels in the diet and this was in agreement with the findings of Hung et al [15] who reported that increasing supplementation of Leucaena pellets decreased the protozoal population. The lower number of protozoa could be due to presence of the CT contained in LS and this was confirmed by the works of Makkar et al [16] and Guo et al [17] who reported the reduction of protozoal populations by feeding CT containing plants. The mean values of bacteria and zoospores were increased with increasing levels of LS, but not at the highest level of CT uptake with $100 \%$ LS. This could be due to the interaction between protozoa and fungal zoospores. According to Newbold and Hillman [18], there was an increase in the numbers of fungal zoospores when protozoa have been removed from the rumen. Moreover, $60 \%$ LS could provide adequate $\mathrm{N}$ source for microbial growth leading to the increasing of bacterial population.

\section{Effect of diet on amylolytic bacteria, proteolytic bacteria and cellulolytic bacteria}

The cellulolytic and proteolytic bacterial population were significantly different among treatments and was the highest in $60 \%$ LS feeding. This could be explained by a decrease of protozoal population leading to an increase of bacterial population as has been reported by Makkar et al [16] as protozoa in rumen have ability to engulf ruminal bacteria. In addition, the increase of the bacterial population could be a result of the increasing protein intake from LS feeding as also reported by Chanjula et al [19]. Moreover LS contains a high level of sulfur which is a factor supporting microbial growth [3]. Tagari et al [20] showed that the growth of cellulolytic and proteolytic bacteria was inhibited by carob tannins in an artificial rumen. Inhibitory activity of tannins against bacteria may be due to the ability of tannins to form complexes with the cell wall and membrane of bacteria causing morphological changes of the cell and the secreted extracellular enzymes [21].

\section{Nitrogen balance and efficiency of microbial protein synthesis}

The increasing $\mathrm{N}$ balance by LS feeding in the present study was in agreement with the finding of Hung et al [15] and Longo et al [22] who reported that feeding Leucaena increases $\mathrm{N}$ balance of swamp buffaloes and sheep. It is clear that Leucaena with high protein content could be a source of more $\mathrm{N}$ for dairy steers. However, fecal $\mathrm{N}$ increased by LS feeding and the highest was

Table 4. Effect of Leucaena silage feeding levels on nitrogen utilization and urinary purine derivatives in dairy steers

\begin{tabular}{|c|c|c|c|c|c|c|}
\hline Items & RST & RLS30 & RLS60 & LS & SEM & Significant level \\
\hline \multicolumn{7}{|l|}{ Nitrogen $(\mathrm{g} / \mathrm{d})$} \\
\hline Intake & $17.8^{\mathrm{a}}$ & $52.5^{b}$ & $94.4^{c}$ & $125.8^{d}$ & 1.81 & ** \\
\hline Fecal & $8.5^{\mathrm{a}}$ & $18.0^{b}$ & $24.0^{c}$ & $50.9^{d}$ & 1.77 & ** \\
\hline Urine & $4.6^{\mathrm{a}}$ & $11.1^{b}$ & $16.2^{c}$ & $30.0^{d}$ & 1.64 & ** \\
\hline Absorption & $9.4^{\mathrm{a}}$ & $34.6^{b}$ & $70.4^{c}$ & $75.0^{c}$ & 1.67 & ** \\
\hline Retention & $4.8^{\mathrm{a}}$ & $23.5^{b}$ & $54.2^{c}$ & $45.0^{d}$ & 2.00 & ** \\
\hline \multicolumn{7}{|c|}{ Urinary purine derivatives (mmol/d) } \\
\hline Allantoin excretion & $44.0^{\mathrm{a}}$ & $66.5^{b}$ & $84.8^{c}$ & $58.5^{d}$ & 1.28 & * \\
\hline Allantoin absorption & $30.2^{\mathrm{a}}$ & $56.9^{b}$ & $77.2^{c}$ & $47.6^{d}$ & 1.57 & * \\
\hline MN supply (g/d) & $22.0^{\mathrm{a}}$ & $41.3^{b}$ & $56.1^{c}$ & $34.6^{d}$ & 1.34 & * \\
\hline EMNS (g/kg OMDR) & $27.2^{\mathrm{a}}$ & $36.8^{b}$ & $40.7^{c}$ & $32.1^{d}$ & 1.48 & * \\
\hline
\end{tabular}

Condensed tannins intake in each treatments was $0.0,28.6,62.2$, and $92.4 \mathrm{~g} /$ head/d for RST, RLS30, RLS60, and LS, respectively: RST, rice straw; RLS30, 70\% rice straw+30\% Leucaena silage; RLS60, 40\% rice straw+60\% Leucaena silage; LS, 100\% Leucaena silage; SEM, standard error of the means; MN, microbial nitrogen supply; EMNS, efficiency of microbial N synthesis ( $\mathrm{g} / \mathrm{kg}$ of organic matter digested in the rumen); OMDR, organic matter digestibility in the rumen (assuming that rumen digestion was $650 \mathrm{~g} / \mathrm{kg}$ dry matter of organic matter digestibility in total tract).

a,b,c,d Means in the same row with different superscript differ $\left.\left({ }^{*} p<0.05\right),{ }^{* *} p<0.01\right)$. 
in steers fed 100\% LS and this could be due to the high CP and CT uptake increasing protein escape from rumen and flow to small intestine. Protein released from tannin-protein complex not only depends on $\mathrm{pH}$ but also on chemical characteristics of tannin molecule [23] and could also attach to endogenous or microbial protein [24]. It has been reported that $\mathrm{N}$ excretion through urine was increased due to CP diet and $\mathrm{N}$ intake [25] and high ruminal degradable proteinratio in dietary protein also increased urine $\mathrm{N}$ [26]. When protein degradation is more rapid than synthesis, ammonia will accumulate in the rumen liquor and is absorbed into the blood, carried to the liver and converted to urea and excreted via urine $\mathrm{N}[27,28]$.

The PD excretion in urine is considered an indicator for estimating the microbial protein productivity in the rumen. Ruminal microbial protein synthesis plays an important role in ruminants because it provides mainly high quantity and quality protein resources for host animal, accounting for $50 \%$ to $80 \%$ of total absorbable protein. However, microbial protein synthesis and efficiency are depend on many factors such as DM intake, rate of ruminal degradability of nitrogen and carbohydrate sources, rumen dilution rate, mineral and other factors [29]. This study showed that microbial protein synthesis was the highest in $60 \%$ LS and followed by 30\% LS, 100\% LS and RS. This could be explained that RS ration had low protein content $(2.4 \% \mathrm{CP})$ which negatively effects microbial growth. The dietary crude protein content required for optimal microbial growth is greater than 11\% CP [30]. Furthermore, CT in LS diets could help in synchronizing release of various nutrients which in turn might be responsible for increased microbial efficiency. However, microbial protein synthesis in 100\% LS has not been improved as compared to $60 \%$ LS and $30 \%$ LS and probably due to the overload protein content in the diet caused an imbalance in protein-energy ration and the effects of higher dietary CT which probably inhibits some rumen bacteria [31].

\section{CONCLUSION}

Based on this study, it could be concluded that $60 \%$ LS was the best level for the replacement of basal RS feeding. This replacement improved the populations of total bacteria, especially proteolytic bacteria and cellulolytic bacteria, meanwhile $\mathrm{N}$ ultilization and microbial protein synthesis were also enhanced. However, further study should be conducted using LS in lactating dairy cow and/or fattening beef cattle to elucidate the effect on milk, meat production and quality.

\section{CONFLICT OF INTEREST}

We certify that there is no conflict of interest with any financial organization regarding the material discussed in the manuscript.

\section{ACKNOWLEDGMENTS}

The authors would like to express their most sincere gratitude and appreciation to Tropical Feed Resources Research and Development Center (TROFREC), Department of Animal Science, Faculty of Agriculture, Khon Kaen university, Thailand and for providing financial support for research and for the use of the research facilities and to the Vietnam International Education Department, Ministry of Education and Training for providing scholarship for the author.

\section{REFERENCES}

1. Wanapat M, Kang S, Polyorach S. Development of feeding systems and strategies of supplementation to enhance rumen fermentation and ruminant production in the tropics. J Anim Sci Biotechnol 2013;4:32.

2. Wanapat M. Potential uses of local feed resources for ruminants. Trop Amin Health Prod 2009;41:1035-49.

3. Aregheore EM. Nutritive and anti-nutritive value of some tree legumes used in ruminant livestock nutrition in Pacific Island countries. J South Pacific Agric 1999;6:50-61.

4. Barros-Rodríguez M, Solorio-Sánchez J, Sandoval-Castro C, et al. Effects of two intake levels of Leucaena leucocephala on rumen function of sheep. Trop Grassl Forrajes Tropicales 2013;1:55-7.

5. AOAC (Association of Official Analytical Chemists). Official methods of Analysis, 16th edn. Animal Feed: Association of Official Analytical Chemists, VA: AOAC International; 1995.

6. Goering HK, Van Soest PJ. Forage fiber analysis (apparatus, reagent, procedures and some application). Agric. Handbook No. 379, ARS, Washington DC: USDA; 1970.

7. Burns RE. Method for estimation of tannin in grain sorghum. Agron J 1971;63:511-2.

8. Wanapat M, Poungchompu O. Method for estimation of tannin by Vanillin-HCL method [a modified method of Burns, 1971]. Manual of laboratory of ruminant nutrition. Department of Animal Science, Khon Kaen University, Khon Kaen, Thailand; 2001.

9. Chen XB, Kyle DJ, Ørskov ER. Measurement of allantoin in urine and plasma by high-performance liquid chromatography with pre-column derivatization. J Chromatogr 1993;617:241-7.

10. Chen XB, Gomes MJ. Estimation of microbial protein supply to sheep and cattle based on urinary excretion of purine derivativesan overview of the technical details. Occassional publication 1992. International Feed Resources Unit, Aberdeen, UK: Rowett Research Institute; 1995.

11. Galyean ML. Laboratory procedure in animal nutrition research. Las Cruces, NM: New Mexico State University; 1989. pp. 107-22.

12. Hungate RE. Chapter IV A roll tube method for cultivation of strict anaerobes. Methods Microbiol 1969; 3:117-32.

13. SAS (Statistical Analysis System) Institute Inc. Guide for Personal Computers. 6th edn. Cary, NC: SAS Institute Inc.; 1998. 
14. Steel RGD, Torrie JH. Principles and procedures of statistic: a biometrical approach. 2nd edn. NY: McGraw-Hill Inc.; 1980.

15. Hung LV, Wanapat M, Cherdthong A. Effects of leucaena leaf pellet on bacterial diversity and microbial protein synthesis in swamp buffalo fed on rice straw. Livest Sci 2013;151:188-97.

16. Makkar HP, Blümmel M, Becker K. In vitro effects of and interactions between tannins and saponins and fate of tannins in the rumen. J Sci Food Agric 1995;69:481-93.

17. Guo YQ, Liu JX, Lu Y, et al. Effect of tea saponin on methanogenesis, microbial community structure and expression of mcrA gene, in cultures of rumen micro-organisms. Lett Appl Microbiol 2008; 47:421-6

18. Newbold CJ, Hillman K. The effect of ciliate protozoa on the turnover of bacterial and fungal protein in the rumen of sheep. Lett Appl Microbiol 1990;11:100-2.

19. Chanjula P, Wanapat M, Wachirapakorn C, Rowlinson P. Effects of various levels of cassava hay on rumen ecology and digestibility in swamp buffaloes. Asian-Australas J Anim Sci 2004;17:663-9.

20. Tagari H, Henis Y, Tamir M, Volcani R. Effect of carob pod extract on cellulolysis, proteolysis, deamination, and protein biosynthesis in an artificial rumen. Appl Environ Microbiol 1965;13:437-42.

21. Smith AH, Zoetendal E, Mackie RI. Bacterial mechanisms to overcome inhibitory effects of dietary tannins. Microb Ecol 2005; 50:197-205.

22. Longo C, Nozella EF, Cabral Filho SLS, Lavorenti N, Vitti DMSS, Abdalla AL. Voluntary intake, apparent digestibility and nitrogen balance by sheep supplemented with Leucaena leucocephala. Livest Res Rur Dev 2008;20:Article \#184.

23. Barahona R, Lascano CE, Cochran R, Morrill J, Titgemeyer EC. Intake, digestion, and nitrogen utilization by sheep fed tropical legumes with contrasting tannin concentration and astringency.
J Anim Sci 1997;75:1633-40.

24. McNeill DM, Osborne N, Komolong MK, Nankervis D. Condensed tannins in the genus Leucaena and their nutritional significance for ruminants. In: Proceedings of the Leucaena-Adaptation, Quality and Farming Systems, Hanoi: 1998. pp. 205-214.

25. Pimpa O, Ruengsuwan S, Pimpa B. Protein requirements for maintenance and growing of Thai southern native cattle: practical feeding trial on farm of South-Thailand. In: Oshio E, Otusuka M, Sommart K. editors. Establishment of a feeding standard of beef cattle and a feed database for the indochiness peninsula. Ibaraki, Japan: JIRCAS, Tsukuba; 2009. pp. 86-89.

26. Javaid A, Nisa M, Sarwar M, Shahzad MA. Ruminal characteristics, blood $\mathrm{pH}$, blood urea nitrogen and nitrogen balance in Nili-ravi Buffalo (Bubalus bubalis) bulls fed diets containing various levels of ruminally degradable protein. Asian-Australas J. Anim Sci 2008; 21:51-8.

27. Mcdonald P, Edwards RA, Greenhalgh JED, Morgan CA. Animal nutrition. 5th edn. Upper Saddle River, NJ: Prentice Hall; 1995.

28. Howard H, O’Kiely P, Moloney AP, O’Mara FP. Intake, digestibility, $\mathrm{N}$ metabolism and growth in growing steers offered zero-grazed grass supplemented with sucrose. Tullamore, Ireland: Agricultural Research Forum, 2007: p. 12-13.

29. Stern MD, Hoover WH. Methods for determining and factors affecting rumen microbial protein synthesis: a review. J Anim Sci 1979; 49:1590-603.

30. Pathak AK. Various factors affecting microbial protein synthesis in the rumen. Vet World 2008;1:186-9.

31. Waghorn GC. Beneficial and detrimental effects of dietary condensed tannins for sustainable sheep and goat productionProgress and challenges. Anim Feed Sci Technol 2008;147:116-39. 